\title{
MEDICINE AND THE LAW \\ Human tissue and organ transplant provisions: Chapter 8 of the National Health Act and its Regulations, in effect from March 2012 - what doctors must know
}

\author{
David McQuoid-Mason
}

Where provisions that were in the Human Tissue Act have been left out of the National Health Act they have been included in its regulations. However, new provisions in the latter Act provide strict controls for the transplantation of organs into non-South African citizens or non-permanent residents, and outlaw the charging of fees for human organs. The provisions also expand the list of persons who can give consent to donations from deceased persons to include 'partners', who now take precedence over all other relatives except spouses. Some of the matters in the Human Tissue Act that were not covered by the National Health Act have now been included in the regulations, such as: $(i)$ the parties responsible for determining death of a person whose organs are to be removed for transplantation purposes; (ii) the requirement that tissue must be harvested within 24 hours from donated bodies; (iii) the removal of eye tissue; (iv) the exclusivity of rights in respect of tissue donations; and $(v)$ confidentiality and publicity regarding tissue and organ transplants.

S Afr Med J 2012;102(9):733-735. DOI:10.7196/SAMJ.6047
On 1 March 2012 the Human Tissue Act ${ }^{1}$ was repealed and the provisions in chapter 8 of the National Health Act $^{2}$ (the Act) dealing with the control and use of blood, blood products, tissue and gametes in humans came into effect. ${ }^{3}$ On 2 March 2012 regulations $^{4}$ were promulgated to incorporate certain provisions in the Human Tissue Act that were not included in the National Health Act. Some of the provisions of the latter and its regulations that doctors need to know about include: (i) tissue donation by living persons; (ii) organ transplantations into non-South African citizens and nonpermanent residents; (iii) donations of human bodies and tissue of deceased persons; (iv) consent to donations of human tissue on behalf of deceased persons; $(v)$ allocation and use of human organs of deceased persons; ( $v i$ ) revocations of donations; (vii) exclusive rights in donations; and (viii) confidentiality and publicity regarding donations.

\section{Tissue donations by living persons}

The Act does not state who may consent to donations of human tissue in the case of living persons. However, the regulations provide that tissue, blood or gametes may not be removed from the body of another living person unless written consent has been granted by donors themselves, if they are older than 18 years, or by the parents or guardians of donors aged under 18 years. ${ }^{5}$ In terms of the Act, persons younger than 18 years may not donate tissue that is not replaceable by natural processes, nor may they donate gametes. ${ }^{6}$

The Act does not list the institutions or persons to whom tissue, blood, blood products or gametes from living persons may be donated, but these are provided for in the regulations: ( $i$ ) hospitals; (ii)

David McQuoid-Mason is Professor of Law at the Centre for Socio-Legal Studies, University of KwaZulu-Natal, Durban, and publishes and teaches in medical law. universities or universities of technology; (iii) authorised institutions; (iv) medical practitioners or dentists; or $(v)$ a tissue bank or any person who requires therapy in which the tissue concerned can be used. ${ }^{7}$

The provisions in the Act restricting payment for the importation, acquisition or supply of tissue, blood, blood products or gametes are specific: it is an offence for a donor of tissue, a gamete, blood or a blood product to receive financial or other reward for such donation except for reimbursing their reasonable costs incurred (e.g. travel costs, medical bills). It is also an offence to sell or trade in tissue, gametes, blood or blood products except as provided for in the Act. ${ }^{8}$ A person convicted of either of these offences may be fined or imprisoned for up to 5 years or both. ${ }^{9}$ However, the Act allows a health care provider registered with a statutory health professional council to receive remuneration for any professional service rendered. ${ }^{10}$

\section{Organ transplants into non-South Africans or non-permanent residents}

A human organ may not be transplanted into a person who is not a South African citizen or a permanent resident without the Minister's written authorisation. ${ }^{11}$ This provision outlaws the type of situation that arose when Israeli patients came to South Africa to receive kidney transplants from their Brazilian 'relatives.'. ${ }^{12}$ It makes no difference that a non-South African or non-permanent resident potential donor is a genuine relative of the donee; approval must still be sought from the Minister. However, if the parties are genuinely related, it is highly likely that the Minister will consent.

Doctors who transplant organs into persons who are not South African citizens or permanent residents without authorisation from the Minister, or who charge a fee for a human organ, as distinguished from a fee for professional services, are guilty of an offence and on conviction may be fined or imprisoned (not exceeding 5 years) or both. ${ }^{13}$

\section{Donations of human bodies and tissue of deceased persons}

Under the Act, ${ }^{14}$ persons competent to make a will may donate their bodies or tissues in a will, or document signed by them and two 
competent witnesses, or in an oral statement in the presence of two competent witnesses. Persons older than 16 years are competent to make a will; ${ }^{15}$ competent witnesses are older than 14 years. ${ }^{16}$ The will, document or statement must nominate the intended donee institution or person, and should specify how the donor's body or tissue should be used after his or her death. Failure to specify a donee renders the donation null and void. However, this does not apply to organs that have been donated for transplantation or treatment, or for medical or dental training or research, provided they are used in the prescribed manner and the donee determined in accordance with the prescribed procedure. ${ }^{17}$

The regulations determine how the donation should be dealt with where no specific institution or donee is named. In such instances, the institution in the appropriate category that is nearest the place where the donor's body or tissue is kept shall be deemed to be the donee. Similarly, if a donation is made to a specific donee who is not within easy reach at the time and place of the death of the donor, the institution in the appropriate category that is nearest to the place of the donor's death shall be deemed to be the donee. Regarding conflicting donations, the regulation states that effect should be given to the donation made last. ${ }^{18}$

While the Act defines death as 'brain death', it does not state by whom this must be determined. The regulations provide that in the case of organ transplantation, the death of the deceased has to be determined by two doctors, one of whom must have been qualified for at least 5 years and neither of whom may be members of the transplant team. ${ }^{19}$

A person who fails to comply with the prescribed conditions regarding the use of human organs obtained from a deceased person for the purpose of transplantation or treatment or medical or dental training or research, or does not allocate human organs in accordance with the prescribed procedures, is guilty of an offence and on conviction is subject to a fine or imprisonment (up to 5 years) or both. ${ }^{13}$

\section{Consent to donations of human tissue on behalf of deceased persons}

Where a donation of tissue has not been made or where the deceased has not prohibited a donation while alive, certain relatives may consent to a donation. The Act provides an order of preference for whom may make a donation in these circumstances, namely the spouse, partner, major child, parent, guardian, major brother or major sister of that person. ${ }^{20}$ Partners take precedence over all other family members except spouses when it comes to donating tissue or the organs of a deceased person, and other family members may not overrule their decision. While other family members may approach the courts if they can show good cause for why the partner's decision should be overruled, the courts are likely to be reluctant to interfere with a partner's decision made according to the provisions of the Act.

The Act provides that where persons legally empowered to consent to tissue or organ donation on behalf of a deceased person cannot be located after 
their death, the Director-General of Health may donate any specific tissue of that person to an institution or a person, provided all the 'prescribed steps' have been taken to locate the person authorised to give consent. ${ }^{21}$ While the General Regulations do not mention what the 'prescribed steps' are, these steps have been published for donations of human biological material for genetic testing, genetic training and genetic health research for therapeutic purposes, in the Regulations for the Use of Human Biological Material. ${ }^{22}$ The latter Regulations require the Director-General to obtain the name, address and telephone number of the spouse, partner, major child, parent, guardian, major brother or major sister of the deceased person from: (i) any person working in the relevant hospital, institution or facility where the deceased died; or (ii) any person who visited the deceased before he or she died..$^{23}$ It is submitted that these steps should also be followed for other donations of human tissue by the Director-General under the National Health Act.

\section{Allocation and use of human tissue and organs from deceased persons}

The Act states that, except in the case of a whole-body donation, where a body has been donated to an institution for removal of tissue, the tissue must be harvested within a period of 24 hours, after which the body may be claimed by the following in the order specified: a spouse, partner, major child, parent, guardian, major brother or major sister. ${ }^{24}$ Relaxed provisions regarding the removal of eye tissue are also included in the regulations. ${ }^{25}$

Except as provided for in any other law, any person who acquires, uses or supplies a body of a deceased person or any tissue, blood or gametes of a living or deceased person in any manner or for any purpose, other than as provided for by the Act and its regulations, is guilty of an offence and liable on conviction to a fine or imprisonment for a period of 10 years or to both. ${ }^{26}$

\section{Revocation of donations}

A donor may, before transplantation of the relevant organ into the donee, revoke the donation in the same way in which it was made. In the case of donation by a will or other document, revocation may be by the intentional destruction of such will or document by the person making it. ${ }^{27}$ Donors may therefore change their mind at any time before transplantation of the organ into the donee. Persons consenting to the donation of tissue or organs on behalf of a deceased person may also change their minds and revoke the donation at any stage. However, it is submitted that such revocations must be done within the limits of good medical practice, for instance not at the last minute when the transplant operation on the donee is already underway.

\section{Exclusive rights in donations}

The Act does not provide that the persons who acquire the body of a deceased person or any tissue, blood or gamete in terms of the Act or its regulations have exclusive rights over them, but the regulations provide for such rights by the donee. ${ }^{28}$

\section{Confidentiality and publicity regarding donations}

The regulations prohibit the publication, without the consent of the appropriate person concerned, of any information that would identify: (i) a deceased person whose body or any specific tissue thereof was donated; (ii) the donor of the body of a deceased person or any specific tissue thereof; (iii) a living person from whose body any tissue, blood or gamete has been removed or withdrawn for any purpose; or (iv) a person who consented to the removal of any tissue, blood or gametes from a living person for such purposes. The regulations also prohibit the publication, without the consent of the appropriate person, of information that would identify the recipient of any tissue removed from the body of a deceased or living person. ${ }^{29}$

\footnotetext{
Human Tissue Act No. 65 of 1983

2. National Health Act No. 61 of 2003.

3. Proclamation No. 11 in Government Gazette No. 35081 of 27 February 2012

4. Government Notices R175-R183 in Government Gazette No. 35099 of 2 March 2012.

5. Regulation 2 of the Regulations Regarding the General Control of Human Bodies, Tissue, Blood, Blood Products and Gametes in Government Notice R180 of Government Gazette No. 35099 of 2 March 2012.

6. Section 56(2) of the National Health Act No. 61 of 2003

7. Regulation 4 of the Regulations Regarding the General Control of Human Bodies, Tissue, Blood, Blood Products and Gametes in Government Notice R180 of Government Gazette No. 35099 of 2 March 2012.

8. Section 60(4) of the National Health Act 61 of 2003

9. Section 60(2) of the National Health Act 61 of 2003.

10. Section 60(3) of the National Health Act 61 of 2003.

11. Section 61(3) of the National Health Act No. 61 of 2003.

1. Section $61(3)$ of the National Health Act No. 61 of 2003 .
2. Khoza SS. The human organ trade: The South African tragedy. South African Journal of Bioethics and Khoza SS. The human

3. Section 61(5) of the National Health Act No. 61 of 2003

14. Section 62(1) of the National Health Act No. 61 of 2003

15. Section 1 of the Wills Act No. 7 of 1953

16. Section 4 of the Wills Act No. 7 of 1953

17. Section 62(1) read with section 61(1) and (2) of the National Health Act No. 61 of 2003

18. Regulation 6 of the Regulations Regarding the General Control of Human Bodies, Tissue, Blood, Blood Products and Gametes in Government Notice R180 of Government Gazette No. 35099 of 2 March 2012.

19. Regulation 9 of the Regulations Regarding the General Control of Human Bodies, Tissue, Blood, Blood Products and Gametes in Government Notice R180 of Government Gazette No. 35099 of 2 March 2012.

20. Section 62(2) of the National Health Act No. 61 of 2003.

21. Section 62(3) of the National Health Act No. 61 of 2003 .

22. Regulations relating to the Use of Human Biological Material in Government Notice R177 of Regulations relating to the Use of Human Biog

23. Regulation 4(2) of the Regulations relating to the Use of Human Biological Material in Government Notice R177 of Government Gazette No. 35099 of 2 March 2012.

24. Regulation 8(1) and (2) of the Regulations Regarding the General Control of Human Bodies, Tissue, Blood, Blood Products and Gametes in Government Notice R180 of Government Gazette No. 35099 of 2 March 2012.

25. Regulation 8(3) of the Regulations Regarding the General Control of Human Bodies, Tissue, Blood, Blood Products and Gametes in Government Notice R180 of Government Gazette No. 35099 of 2 March 2012.

26. Section 25(a) of the Regulations Regarding the General Control of Human Bodies, Tissue, Blood, Blood Products and Gametes in Government Notice R180 of Government Gazette No. 35099 of 2 March 2012.

27. Section 65 of the National Health Act No. 61 of 2003.

28. Regulation 26 of the Regulations Regarding the General Control of Human Bodies, Tissue, Blood, Blood Products and Gametes in Government Notice R180 of Government Gazette No. 35099 of 2 March 2012.

29. Regulation 24 of the Regulations Regarding the General Control of Human Bodies, Tissue, Blood, Blood Products and Gametes in Government Notice R180 of Government Gazette No. 35099 of 2 March 2012.
} 